Gut, 1981, 22, 277-282

\title{
Mucosal cell proliferation in duodenal ulcer and duodenitis
}

\author{
C J BRANSOM, M E BOXER, K R PALMER, J C CLARK, J C E UNDERWOOD, \\ AND H L DUTHIE
}

From the University Departments of Surgery and Pathology, The Royal Hallamshire Hospital, Sheffield

SUMMARY Mucosal cell proliferation in the first part of the duodenum was studied in 24 patients using a tissue culture technique in which endoscopic biopsies were subjected to autoradiography after exposure to tritiated thymidine. Eight patients had a normal duodenum, eight had duodenal ulcer, and eight had symptomatic chronic non-specific duodenitis. The mean crypt labelling index (LI) in normal duodenum was $8 \cdot 8 \pm 0.4 \%$ (SEM). Increased labelling indices of $15.6 \pm 1.7 \%$ were found near the edge of duodenal ulcers and $17 \cdot 8 \pm 1 \cdot 8 \%$ in duodenitis. Treatment with cimetidine reduced both the severity of duodenitis and the mean crypt LI. The LI of histologically normal duodenal mucosa distal to ulcer or duodenitis was similar to that of the control subjects' mucosa. The increased mucosal cell proliferation seen in severe duodenitis, either alone or associated with duodenal ulceration, suggested that erosions and ulcers arose when the crypts passed into 'high output failure' and were unable to compensate for further epithelial cell loss. There was no evidence in our study for a generalised failure of mucosal cell proliferation in duodenal ulcer or duodenitis.

Interest in the pathophysiology of duodenal ulceration has centred on gastric acid and possible abnormalities in the regulation of acid secretion. ${ }^{12}$ Less is known of the mucosal changes that result in the discrete ulcer $^{34}$ or whether there is a generalised defect in mucosal repair in ulcer patients. ${ }^{5}$ The relationship between non-specific duodenitis and ulcer disease remains controversial..$^{6-8}$ This study was undertaken to provide information on the simple question posed by Eastwood ${ }^{9}$ of whether or not there is a failure of epithelial renewal in duodenal disease.

\section{Methods}

\section{PATIENTS}

Endoscopically and histologically normal duodenal mucosa was biopsied in eight control subjects, four men, mean age 51.8 years (range 43-57 years) whose diagnoses proved to be pelviureteric obstruction, myocardial ischaemia, gall stones, and anxiety state, and four women, mean age $56 \cdot 8$ years (range 48-71 years), three having hiatus hernia and one gallstones.

The duodenal ulcer patients were six men, mean age $41 \cdot 5$ years (range $32-75$ years) and two women

Received for publication 10 November 1980 of 68 and 40 years. Mucosa from patients with symptomatic duodenitis in the absence of an ulcer was biopsied in seven men, mean age 42.9 years (range 34-58 years) and a woman of 39 years.

Ten patients (two controls with hiatus hernia, three ulcer and five duodenitis) were rebiopsied after a four week course of cimetidine $1 \mathrm{~g}$ /day.

\section{PROCEDURES}

After anaesthetising the oropharynx, the patients were sedated with diazepam and given atropine or hyoscine as required. Four biopsies were taken with the Olympus GIF $\mathbf{K}$ endoscope from the normal bulb, ulcer edge, or area of duodenitis; additional biopsies were taken from the distal first part of duodenum away from obviously pathological mucosa. Biopsies were placed in iced Hanks solution and transferred to $5 \mathrm{ml}$ of Medium 199 with Hanks salts and Hepes buffer (Gibco Bio-Cult Ltd.) in $25 \mathrm{ml}$ Erlenmeyer flasks at a pH of 7.0-7.2. The flasks were gently agitated in a water bath at 37$38^{\circ} \mathrm{C}$, and were continuously gassed with humidified filtered $95 \%$ oxygen and $5 \%$ carbon dioxide. After 20 minutes, $20 \mu \mathrm{Ci} / \mathrm{ml}$ methyl $-{ }^{3} \mathrm{H}$ thymidine were added (Radiochemical Centre, Amersham, specific activity $24 \mathrm{Ci} / \mathrm{mmol}$ ) and the tissue incubated for an additional 30 minutes. The biopsies were washed in Hanks solution and incubated for a final $\mathbf{2 0}$ minutes 
in medium without isotope to elute non-specifically attached label. After a wash in Hanks solution the biopsies were orientated on a strip of card under a stereo microscope, and fixed in buffered formol saline.

Longitudinal sections $4 \mu \mathrm{m}$ thick were coated with Ilford $\mathrm{K} 2$ emulsion and exposed for four weeks at $4^{\circ} \mathrm{C}$. The autoradiographs were developed in Kodak D 19 at $20^{\circ} \mathrm{C}$, fixed with $30 \%$ aqueous sodium thiosulphate, stained with haematoxylin and eosin, and examined under oil immersion using a LeitzDialux 20 EB microscope with E 35 graticule (Graticules Ltd., Tonbridge).

Two-thirds of the biopsies proved satisfactory for quantification. Fifteen to 20 longitudinal crypt sections were counted including Paneth and enterochromaffin cell nuclei, yielding samples of 15002000 crypt cell nuclei per biopsy. Significant levels of labelling were determined by reference to control slides, 5 grains per nucleus being the minimum level used in the study. The percentage ratio of labelled nuclei to total nuclei gave the labelling index (LI) with mean $95 \%$ confidence limits of $\pm 20 \%$, range $10-25 \%$. The nuclei within the proliferative zone, delimited by the highest labelled nucleus in the crypt, were also counted.

Non-autoradiographed sections were stained with haematoxylin and eosin and the periodic acid Schiff method for pathological grading of duodenitis by two independent observers using the criteria of Whitehead. ${ }^{8}$ Statistical comparisons were performed by the Wilcoxon rank sum test.

\section{Results}

\section{LABELLING INDICES}

Autoradiographs of control subjects' mucosa, ulcer edge and duodenitis are illustrated in Figs. 1-3. The
Fig. 1 Duodenum from control subject showing normal villous patterns and inflammatory cell infiltrate. $\times 215$ (original magnification).
Fig. 2 Edge of duodenal ulcer showing loss of villi and tissue disorganisation with increased cellularity of the epithelium, areas of gastric metaplasia and a heavy inflammatory cell infiltrate. $\times 215$ (original magnification).
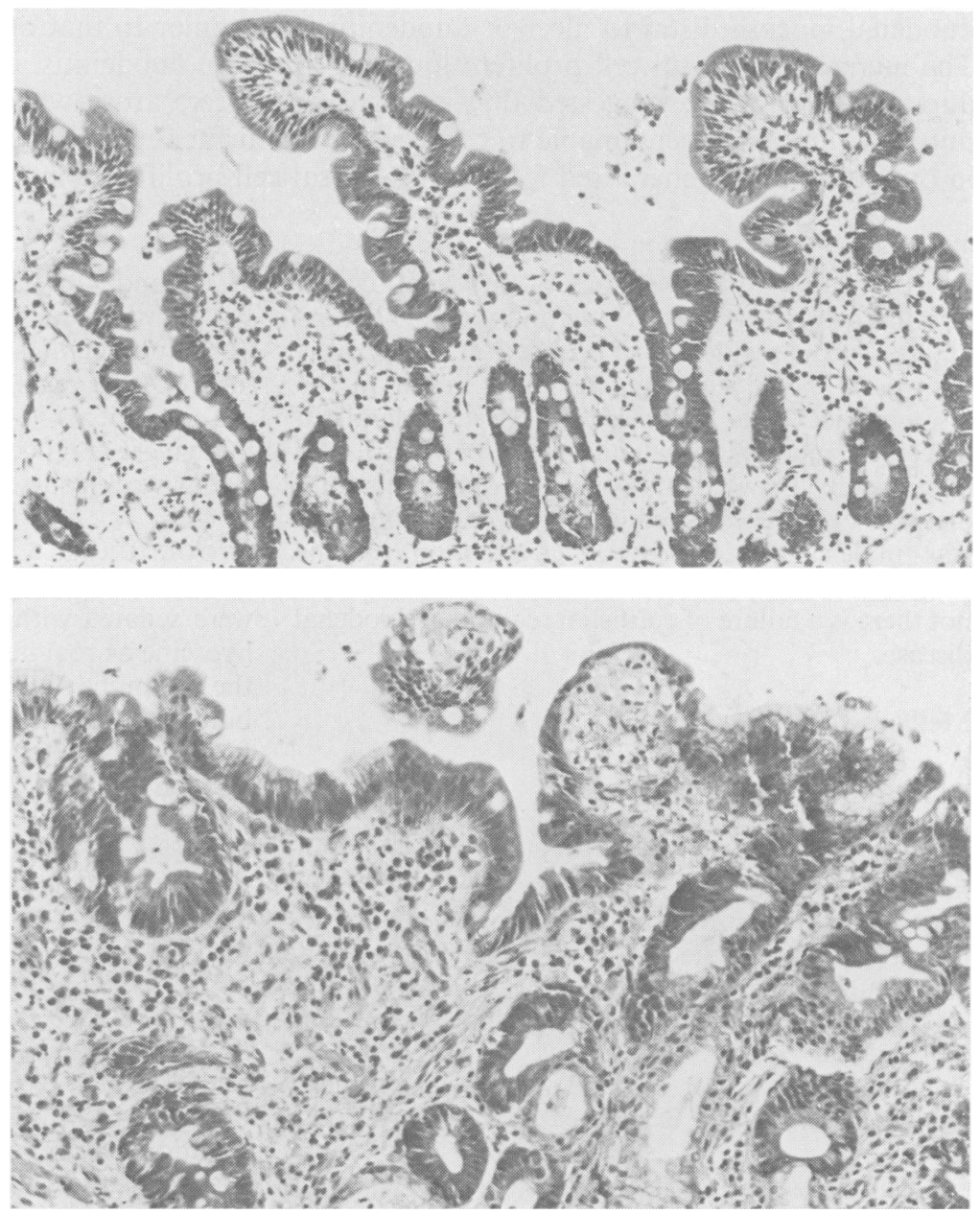


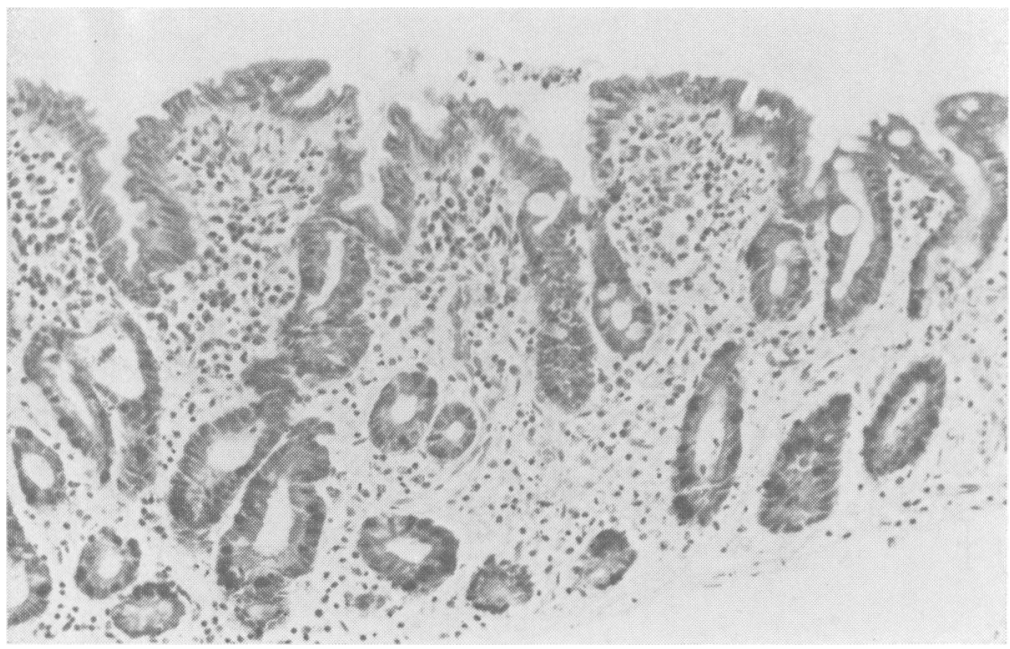

Fig. 3 Grade 2 duodenitis showing villous shortening, irregularity of the superficial epithelium and moderate inflammatory cell infiltrate. $\times 215$ (original magnification).

mean labelling indices for the bulb and distal first part of duodenum of each group of patients are given in the Table. The mean number of labelled and mean total number of nuclei per crypt section for biopsies from the control subjects, ulcer and duodenitis patients are plotted in Fig. 4. There were significant increases $(P<0.05)$ in the mean labelled nuclei per crypt in both ulcer and duodenitis compared with the controls, as well as a significant decrease in the mean total nuclei per crypt in duodenitis $(P<0.05)$.

In mucosa from the bulb of control subjects the proliferative zone comprised $75 \cdot 5 \pm 1 \cdot 7 \%$ (mean \pm SEM) of the total crypt nuclei (range 62:8-83.1). In patients with ulcers the proliferative zone in the bulb included $91 \cdot 3 \pm 2 \cdot 2 \%$ (range $82 \cdot 8-100 \cdot 0$ ) and in duodenitis $92 \cdot 1 \pm 1 \cdot 4 \%$ (range $86 \cdot 6-97 \cdot 3$ ) of the crypt nuclei, both being significantly increased above the normal $(\mathrm{P}<0.01)$.

PATHOLOGICAL GRADING

Pathological grading of the biopsies revealed a trend towards an increased LI with increasing severity of duodenitis (Fig. 5). There were significant differences

Table Labelling indices $\%$, mean \pm SEM, range, and number of biopsies

\begin{tabular}{llll}
\hline & Normal & Duodenal :slcer & Duodenitis \\
\hline Bulb & $\mathbf{8 \cdot 8} \pm 0 \cdot 4$ & $15 \cdot 6 \pm 1 \cdot 7^{*}$ & $17 \cdot 8 \pm 1 \cdot 5 *$ \\
& $(7 \cdot 0-10 \cdot 1)$ & $(8 \cdot 7-21 \cdot 0)$ & $(14 \cdot 6-25 \cdot 5)$ \\
Distal first part & $\mathbf{n}=19$ & $\mathbf{n}=21$ & $\mathrm{n}=24$ \\
of duodenum & $(7 \cdot 1-10 \cdot 9)$ & $\mathbf{1 0 \cdot 0} \pm 1 \cdot 0$ & $12 \cdot 4 \pm 1 \cdot 3$ \\
& $\mathrm{n}=17$ & $\mathbf{n}=13$ & $(7 \cdot 6-19 \cdot 0)$ \\
& & & $\mathrm{n}=18$ \\
\hline
\end{tabular}

-Significantly different from the normal, $\mathrm{P}<0 \cdot 01$. between normal subjects' mucosa and grade 1 duodenitis $(\mathrm{P}<0.01)$, between duodenitis grades 1 and $2(P<0.05)$, but not between grades 2 and 3 . In this study, mucosa from control subjects had a slightly lower mean $\mathrm{LI}(8 \cdot 9 \pm 0.3 \%)$ than normal mucosa from ulcer and duodenitis patients $(10.5 \pm$ $1.2 \%) \quad(P<0.02)$. Ulcer edge biopsies showed

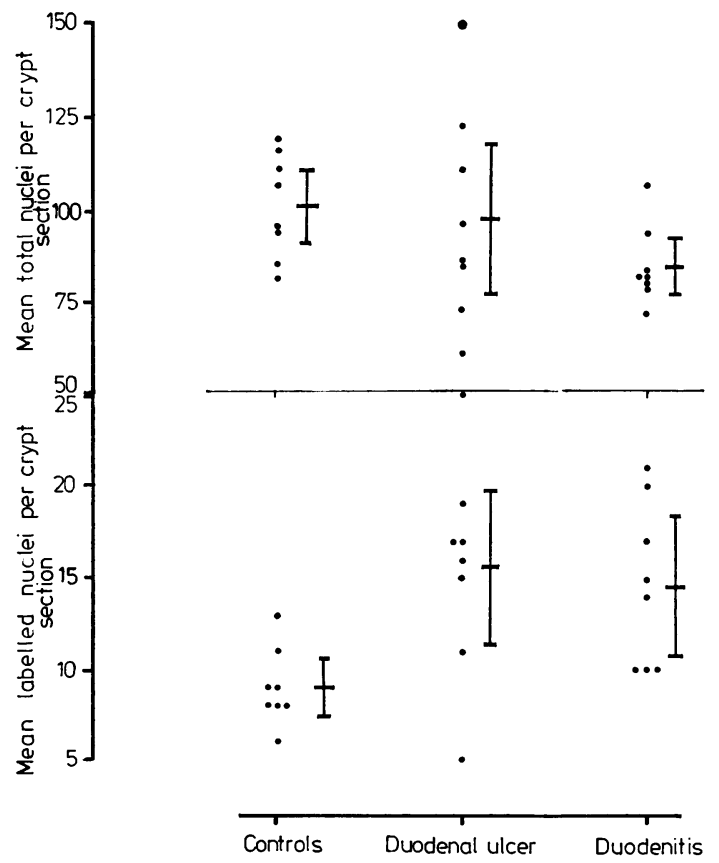

Fig. 4 Mean labelled nuclei and mean total nuclei per crypt section in control subjects, duodenal ulcer, and duodenitis patients (mean $\pm 2 S E M$ ). 


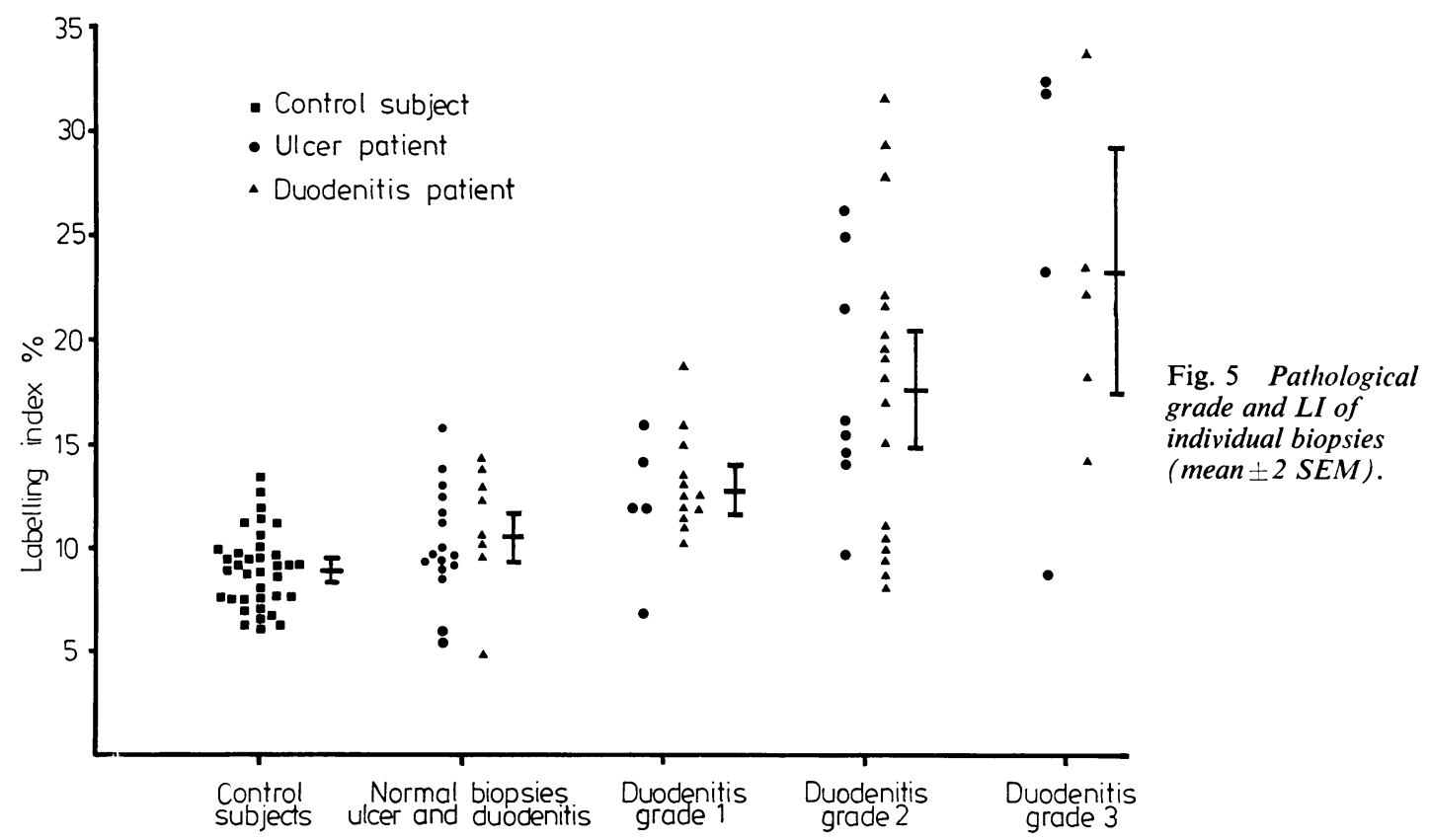

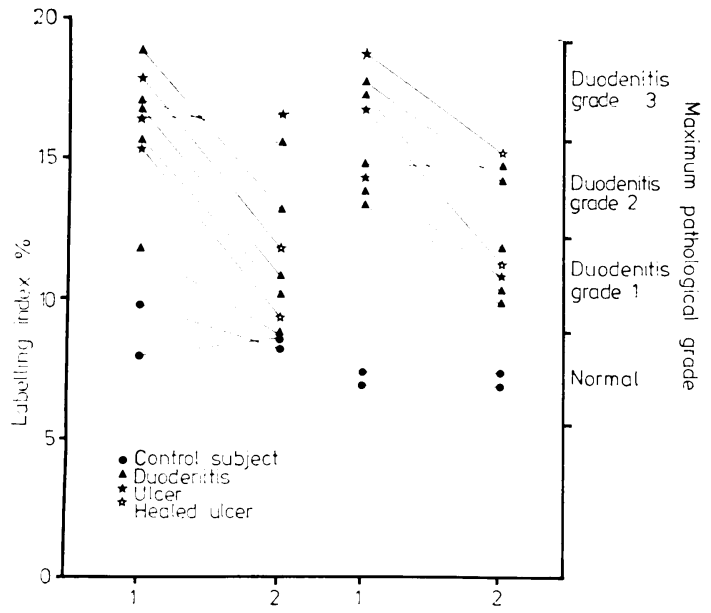

Fig. 6 Comparison of mean LI per patient and maximum pathological grade before (1) and after (2) four week's cimetidine therapy.

duodenitis, there being no significant differences between the LI of ulcer-associated and non-ulcerassociated duodenitis within each pathological grade.

\section{CIMETIDINE THERAPY}

In the 10 subjects rebiopsied after cimetidine, the majority showed a fall both in the mean LI $(P<0.01)$ and in the maximal grade of duodenitis apparent
(Fig. 6). There was little effect of cimetidine on the normal mucosa; the mean LI was $8.4 \pm 0.5 \%$ for control subjects and $9.7 \pm 0.6 \%$ for normal biopsies from ulcer and duodenitis patients. In grade 1 duodenitis after cimetidine the mean LI was 13.6 $\pm 1 \cdot 1 \%$ similar to that in pre-treatment biopsies, but in grade 2 duodenitis the mean LI after cimetidine fell to $10 \cdot 8 \pm 1.0 \%$ significantly lower than in the untreated state $(\mathrm{P}<0.02)$.

\section{Discussion}

Although duodenal ulcer is common, little is known of the mucosal dynamics in ulcer patients. The labelling of DNA-synthesising cells with tritiated thymidine affords an insight into mucosal cell kinetics, ${ }^{10}$ but the technique is limited in vitro by the diffusion distance of tritiated thymidine from the medium into the tissue. ${ }^{11}$ The successful application of the technique to endoscopic biopsies of gastric mucosa $\mathrm{a}^{12}$ encouraged our study of the duodenum, high concentration of tritiated thymidine of $20 \mu \mathrm{Ci} /$ $\mathrm{ml}$ being required to achieve reliable penetration of the biopsies.

Eastwood $^{9}$ proposed two contrasting hypotheses: either 'delayed epithelial renewal contributed to ulcerogenesis by retarded healing' or the ulcer might act as 'a stimulus to epithelial regeneration'. Such effects might be confined to the ulcer edge or be operative in the duodenal mucosa in general. In our study, biopsies from ulcers and areas of duodenitis 
were interpreted as showing an increased prevalence of DNA-synthesising cells, confirmed by finding a two-fold increase in the LI on quantification. This implied accelerated epithelial renewal rather than any retardation of cell division in the pathological mucosa. But interpretation of changes in LI alone may be misleading as the differences may have been in either the S-phase or total cell component of the index. ${ }^{1314}$ However, the predomintent change in both ulcer and duodenitis was an increase in mean number of S-phase cells per crypt. The mean total cell number per crypt was unchanged in ulcer, though the wide range in the samples suggested crypt hyperplasia in some and crypt shortening in others. There was a small reduction in the mean total crypt population in the duodenitis samples, which made a minor contribution to the raised $\mathbf{L I}$ in this condition.

The proliferative zone in the control subjects corresponded to $75 \%$ of the total crypt nuclei, somewhat greater than the 'lower two-thirds of the crypts' recorded in human duodenum in vivo ${ }^{15}$ but similar to the value of $72 \%$ determined in normal human jejunum by the mitotic index distribution method. ${ }^{14}$ The definition of the proliferative zone in our biopsies depended on the site of the highest labelled nucleus, a method which gives a relatively large value for the proliferative zone as not infrequently the highest labelled nucleus was some distance from the majority of the labelled cells. However, there was a clear expansion of the proliferative zone to around $90 \%$ of the total nuclei in the ulcer and duodenitis crypts, supporting the histochemical evidence for accelerated cell differentiation in these conditions. ${ }^{16}$

Normal mucosa from ulcer and duodenitis patients had a mean LI of $10.5 \pm 1.2 \%$ similar to the overall mean LI of $8.9 \pm 0.3 \%$ for control subjects. This suggested that there was no generalised failure in epithelial renewal in the mucosa of ulcer or duodenitis patients. The slight increase in LI in the normal mucosa of the ulcer and duodenitis group was significant $(P<0.02)$, but the inherent inaccuracy of nuclear counting prohibits drawing conclusions from such small differences. Furthermore, the difficulties in distinguishing grade 1 duodenitis from the normal state make it likely that this slight increase in the mean LI of 'normal' tissue from ulcer and duodenitis patients may have been due to inadvertent inclusion of grade 1 duodenitis in our 'normal' group. The normality of the mucosa distal to the ulcer or duodenitis in our survey was in keeping with the earlier studies using the mitotic index method. ${ }^{17} 18$

Eastwood's second hypothesis was that an ulcer might act as 'a stimulus to epithelial regeneration'. Our evidence indicated that the presence of an ulcer provided no greater stimulus than already existed in grade 3 duodenitis alone. The increased LI in severe duodenitis in our study was in agreement with the results of Gorelick et al. ${ }^{19}$ The pathological grading of duodenitis provided strong evidence for accelerating mucosal cell proliferation with increasing severity of duodenitis. This parellels the findings in gastritis. ${ }^{2021}$ Perhaps the feedback mechanisms experimentally shown to link crypt cell generation to villous integrity ${ }^{22} 23$ were already maximally active in grade 3 duodenitis. Epithelial regeneration would then have been incapable of further increase thus contributing to ulcer formation.

The similarity in the increases in LI seen in ulcer and non-ulcer associated duodenitis in our study has been striking. As patients with dyspepsia have been more carefully investigated, often with repeated endoscopy, the clinical similarities between duodenal ulcer and non-ulcer associated duodenitis have also become apparent. ${ }^{7}$ The evidence in this study has been consistent with the concept that duodenitis and ulcer represent stages in the continuum of duodenal peptic disease. In grade 1 and 2 duodenitis the crypts may have compensated for accelerated surface losses, the epithelium remaining intact. In grade 3 duodenitis with surface erosions the crypts may have passed into 'high output failure'; despite accelerated epithelial cell production, surface integrity has broken down. An acute ulcer might have similar implications, with healing dependent on reduction in the loss of surface cells, as suggested by the fall in LI after cimetidine therapy. Once a large chronic ulcer has formed, the associated tissue disorganisation and crypt shortening at the ulcer edge would render healing more difficult despite active mucosal cell proliferation.

We thank Dr C D Holdsworth for allowing us to study his patients and acknowledge the advice and supervision of Professor A G Johnson, the statistical guidance of $\mathrm{Dr} M$ Maher, and the secretarial assistance of Mrs M Hogg.

\section{References}

${ }^{1}$ Wormsley KG. The pathophysiology of duodenal ulceration. Gut 1974; 15: 59-81.

${ }^{2}$ Grossman MI. Abnormalities of acid secretion in patients with duodenal ulcers. Gastroenterology 1978; 75: 524-6.

${ }^{3}$ Kirk RM. Can the singularity of chronic peptic ulcers be described by catastrophe theory and explained by bio feedback? Gastroenterology 1977; 73: 608-10.

'Sircus W. The enigma of peptic ulcer. Scott Med J 1979; 24: 31-7.

${ }^{5}$ McMinn RH. Tissue repair. London: Academic Press, 1969: 247 
'Cheli, R, Aste H. In: Duodenitis. Stuttgart: Georg Thieme, 1976: 68-75.

'Joffe SN, Lee FD, Blumgart LH. Duodenitis. Clin Gastroenterol 1978; 7: 635-50.

${ }^{8}$ Whitehead R. In: Mucosal biopsy of the gastrointestinal tract. Philadelphia: Saunders, 1979: 79-86.

${ }^{\circ}$ Eastwood GL. Gastrointestinal epithelial renewal. Gastroenterology 1977; 72: 962-75.

${ }^{10}$ Aherne WA, Camplejohn RS, Wright NA. An introduction to cell population kinetics. London: Arnold, 1977: 27-43.

${ }^{11}$ Steel GG. Growth kinetics of tumours. Oxford: Clarendon Press, 1977: 107.

${ }^{12}$ Hart Hansen O, Pedersen T, Larsen JK. A method to study cell proliferation kinetics in human gastric mucosa. Gut 1975; 16: 23-7.

${ }^{13}$ Willems G. Cell population kinetics in the mucosa of the gastrointestinal tract. In: Duthie HL, Wormsley KG, eds. Scientific basis of gastroenterology. London: Livingston, 1979: 2-25.

${ }^{14}$ Wright $\mathrm{N}$, Watson A, Morley A, et al. Cell kinetics in flat (avillous) mucosa of the human small intestine. Gut 1973; 14: 701-10.

${ }^{15}$ MacDonald WC, Trier MD, Everett NB. Cell proliferation and migration in the stomach, duodenum and rectum of man. Gastroenterology 1964; 46: 405-17.

${ }^{16}$ Lance P, Filipe I Wastell C. A new classification for duodenitis. Br J Surg 1979; 66: 360-1.
${ }^{17}$ Bertalanffy FD, Nagy KP. Mitotic activity and renewal rate of the epithelial cells of human duodenum. Acta Anat (Basle) 1961 ; 45: 362-70.

${ }^{18}$ Teir $H$, Räsänen T. A study of mitotic rate in renewal zones of nondiseased portions of gastric mucosa in cases of peptic ulcer and gastric ulcer. $J$ Natl Cancer Inst 1961; 27: 949-64.

${ }^{19}$ Gorelick F, Sheahan D, DeLuca V, et al. In vitro ${ }^{3} \mathrm{H}$ thymidine uptake in duodenal mucosa from patients with duodenal ulcer or duodenitis. Gastroenterology 1979; 76: 1141.

${ }^{20}$ Croft DN, Pollock DJ, Coghill NF. Cell loss from human gastric mucosa measured by estimation of deoxyribonucleic acid (DNA). in gastric washings. Gut 1966; 7: 333-43.

${ }^{21}$ Hart Hansen O, Johansen AA, Larsen JK, et al. Relationship between gastric acid secretion, histopathology, and cell proliferation kinetics in human gastric mucosa. Gastroenterology 1977; 73: 453-6.

${ }^{22}$ Galhaard, H, Van Der Meer-Fieggen W, Giesen J. Feedback control by functioning villus cells on cell proliferation and maturation in intestinal epithelium. Exp Cell Res 1972; 73: 197-207.

${ }^{23}$ Rijke RPC, Hanson WR, Plaisier HM, et al. The effect of ischaemic villus cell damage on crypt cell proliferation in the small intestine. Gastroenterology 1976; 71 : 786-892. 